\title{
Weight Test of Broiler Chicks Placed on Probiotic- fortified Composite Feed, Standard Commercial Starter Mash and Cornmeal
}

\author{
Ihuoma Q. Onu-Okpara, Solomon U. Oranusi, Hilary I. Okagbue
}

\begin{abstract}
The study was carried out to compare growth performance results among broiler chicks placed on probioticfortified animal feed (G3), Feed Mill of Nigeria starter mash (G1) (conventional feed) and cornmeal (G2) diets. A total of thirty 1-day-old mixed-sex Agricol broiler chicks were randomized into three groups of 10 chicks each and placed on $600 \mathrm{~g}$ ( $300 \mathrm{~g}$ morning, $300 \mathrm{~g}$ evening) of the respective diets. Feeding test was carried out for the duration of four weeks. The chicks were weighed weekly and data collected was statistically analyzed using a one-way Analysis of variance to check for significant differences in weight among groups. From data analyzed, chicks in groups G3 - probiotic-fortified feed and G1 Feed Mill of Nigeria starter mash, showed no significant difference in parameters (weight) analyzed $(p<0.05)$ and performed better in comparison to chicks placed on cornmeal diet (G2). This study shows that probiotic-fortified feed can be used as a substitute to conventionally-produced feed and yield similar growth performance without the use of feed additives which have adverse effects on animals being fed.
\end{abstract}

Keywords : Animal feed, food waste, probiotics, agricultural waste, growth performance, poultry.

\section{I.INTRODUCTION}

It is is common knowledge that conventionally-produced feed, even while yielding good growth performance results in poultry, has been implicated in the rapid spread of antibiotic resistance genes [1-2] and in the bioaccumulation [3] and biomagnification of toxic feed additives included as feed additives. Because of these consequences, it has become necessary for a shift from conventional feed to safer, environmentally friendly options, which would yield similar, if not better results in terms of animal productivity. Animal feeding tests in which feed material, supplemented with probiotic organisms were used, have been reported to yield positive results in animal growth performance [4-7]. Resistance to some identified diseases [8] and treatment of drinking water [9] may also be the motivation for supplemented feed materials.

Revised Manuscript Received on February 05, 2020.

* Correspondence Author

Ihuoma Q. Okpala*, Department of Biological Sciences, Covenant University, Ota, Nigeria

Solomon U. Oranusi, Department of Biological Sciences, Covenant University, Ota, Nigeria.

Hilary I. Okagbue, Department of Mathematics, Covenant University, Ota, Nigeria.

smoussa@cud.ac.ae

(C) The Authors. Published by Blue Eyes Intelligence Engineering and Sciences Publication (BEIESP). This is an open access article under the CC BY-NC-ND license (http://creativecommons.org/licenses/by-nc-nd/4.0/)

With high growth performance results, supplemented feed materials or direct-fed microbial have begun to be used in place of conventional feed. Moreover, the effects of supplemented feed materials will help to provide sustainable agricultural wastes [10]. Details on the effects of alternative feeds on broilers such as the use of fennel extract additions can be sourced from [8].

\section{II.MATERIALS AND METHODS}

Ethical approval for this study was obtained from the Health and Research Ethics Committee, Covenant University (CHREC/007/2019). Composite feed was formulated from food and agricultural waste material sourced from Cafeteria 2, Covenant University, Ogun State. Proximate analysis test was carried out on waste materials and feed was formulated using the Pearson's square. $1.5 \mathrm{x}$ $10^{5} \mathrm{CFU} / \mathrm{g}$ live culture of the probiotic organism Lactobacillus fermentum was inoculated into composite feed and incubated at $37^{\circ} \mathrm{C}$ for $24 \mathrm{hrs}$ to acidify to the $\mathrm{pH}$ of 4.2

Thirty 1-day-old Agricol broiler chicks were weighed on day of birth and randomized into 3 groups of 10 chicks each and fed daily with a weighed quantity of diets - G1 - Feed Mill of Nigeria (FMN), G2 - Cornmeal and G3 - Probioticfortified composite feed respectively per group. The chicks were cared for under the guidelines laid down by the Covenant University Health and Research Ethics Committee. Growth comparison feeding test was carried out for 4 weeks, with chicks being weighed weekly. Statistical analysis of data (weight) collected was statistically analyzed using the one-way Analysis of Variance test and Tukey's HSD multiple comparison tests in SPSS version 25 to test for significant differences among groups.

\section{III.RESULTS AND DISCUSSION}

From raw data collected, progression in weight of chicks on the respective diets shows that chicks fed Feed Mill of Nigeria starter mash (G1) and probiotic-fortified composite feed (G3) diets performed better in terms of growth performance when compared to chicks placed on cornmeal (G2). Differences in mean weights and standard error of mean weights of chicks in groups G1 and G3 differ less than mean weights of chicks in group (G2). Data on mean weight obtained from chicks in G1 and G3 show that diets yielded similar results in terms of growth performance (Table 1).

Table 1: Mean weight and standard error of mean weight of chicks in G1, G2 and G3.

$$
\text { Group }
$$

G1 G2 G3


Weight Test of Broiler Chicks Placed on Probiotic-fortified Composite Feed, Standard Commercial Starter Mash and Cornmeal

\begin{tabular}{lrrr}
\hline & Mean & Mean & Mean \\
\hline Week 0 & 36.56 & 37.11 & 36.15 \\
Week 1 & 87.2 & 64.8 & 75.9 \\
Week 2 & 167.1 & 105.6 & 168.1 \\
Week 3 & 338.7 & 186.7 & 321.9 \\
Week 4 & 369.9 & 213.1 & 367.4 \\
\hline
\end{tabular}

G1 - Feed Mill of Nigeria starter mash, G2 - cornmeal, G3 - probioticfortified composite feed

A Tukey's HSD multiple comparism test (Table 2) was carried out to determine exact groups with significant differences across weeks.

Groups G1 and G3 show no significant difference in growth performance of chicks $(\mathrm{p}<0.05)$ when compared to chicks in group G2.

This shows the feasibility of substituting conventionallyproduced feed (G1) with probiotic-fortified feed (G2) with similar results in growth performance of chicks occurring. Shareef and Al-Dabbagh [11] obtained an improved growth rate on feeding poultry probiotic supplemented diets. Increased feed conversion was observed by Hassanein and Soliman [12] when poultry was fed yeast supplemented diets.

\section{IV.CONCLUSION}

The research has shown that with probiotic-fortified feed performing as well as conventionally produced feed as seen in the data obtained from weight analyzed. There is the possibility of substituting conventional feed which has been implicated in adverse health benefits to the animal being fed and ultimately to the consumer of the animal, with the probiotic-fortified feed formulated in this study.

\section{ACKNOWLEDGEMENT}

Covenant University is acknowledged for the sponsorship of this research.

\section{REFERENCES}

1. Sivagami K, Vignesh V, Srinivasan R, Divyapriya G, and Nambi I. 2018. Antibiotic usage, residues and resistance genes from food animals to human and environment: An Indian scenario. Journal of Environmental Chemical Engineering, 10.1016/j.jece.2018.02.029.

2. Abdulrasaq, O.O., Benson, N.U., Williams, A.B. \& Msagati, T.A.M. (2019). Target Analysis of Antibiotic Drugs in Poultry Feedstuff by Solid Phase Extraction and Ultra-High Performance Liquid Chromatography-Tandem Mass Spectrometry. Journal of Physics: Conference Series, 1299(1), Article number 012102.

3. Kan C and Meijer G. 2007. The risk of contamination of food with toxic substances present in animal feed. Animal Feed Science and Technology 133: 84-108.

4. Gao J, Zhang H, Yu S, Wu S, Yoon I, Quigley J, Gao Y, Qi G. 2008. Effects of yeast culture in Broiler Diets on Performance and Immunomodulatory functions. Poultry Science 87: 1377-1384.

5. Amiranashvili L, Gagelidze N, Makaradze L, Varsimashvili K, Tolordava L, Tinikashvili L, Amashukeli N, Sachaneli-Qadagishvili T, Kirtadze E. 2017. The effect of homoprobiotc preparation

Table- 2: Multiple comparison test for significant differences in weight among groups across weeks Multiple Comparisons

'Probiogeo' supplemented with drinking water and feed on survivability and growth performance of broiler-chicks. Annals of Agrarian Science 15(4): 476-479.

6. Hussein E and Selim S. 2018. Efficacy of yeast and multi-strain probiotic alone or in combination on growth performance, carcass traits, blood biochemical constituents and meat quality of broiler chickens. Livestock Science 216: 153-159.

7. Shurson G. 2018. Yeast and yeast derivatives in feed additives and ingredients: Sources, characteristics, animal responses and quantification methods. Animal Feed Science and Technology 235: 60-76.

and Salem AZM. 2018. Effect of dietary Foeniculum vulgare Mill. extract on growth performance, blood metabolites, immunity and ileal microflora in male broilers. Agroforestry Systems

10.1007/s10457-018-0326-3.

9. Oke OE, Emeshili UK, Iyasere OS, Abioja MO, Daramola JO, Ladokun AO, Abiona JA, Williams TJ, Rahman SA, Rotimi SO, Balogun SI and Adejuyigbe AE. 2017. Physiological responses and performance of broiler chickens offered olive leaf extract under a hot humid tropical climate. Journal of Applied Poultry Research 26: 376382.

10. Efeovbokhan, V.E., Egwari, L., Alagbe, E.E., Adeyemi, J.T. \& Taiwo, O.S. (2019). Production of bioethanol from hybrid cassava pulp and peel using microbial and acid hydrolysis. BioResources, 14(2), 2596-2609.

11. Shareef AM and Al-Dabbagh ASA. 2009. Effects of probiotic Journal of Veterinary Sciences 23 (Suppl. 1): 23-29.

12. Hassanein SM and Soliman KN. 2010. Effects of probiotic (Saccharomyces cerevisiae) adding to diets on intestinal microflora and performance of Hy-Line layer hens. Journal of American Science 6: 159-169. 
Tukey HSD

\begin{tabular}{|c|c|c|c|c|c|c|c|}
\hline \multirow[t]{2}{*}{ Dependent Variable } & \multirow[t]{2}{*}{ (I) Group } & \multirow[t]{2}{*}{ (J) Group } & \multirow{2}{*}{$\begin{array}{c}\text { Mean } \\
\text { Difference (I-J) }\end{array}$} & \multirow[t]{2}{*}{ Std. Error } & \multirow[t]{2}{*}{ Sig. } & \multicolumn{2}{|c|}{ 95\% Confidence Interval } \\
\hline & & & & & & Lower Bound & Upper Bound \\
\hline \multirow[t]{6}{*}{ Week 0} & G1 & G2 & -.55000 & 1.36913 & .915 & -3.9446 & 2.8446 \\
\hline & & G3 & .41000 & 1.36913 & .952 & -2.9846 & 3.8046 \\
\hline & G2 & G1 & .55000 & 1.36913 & .915 & -2.8446 & 3.9446 \\
\hline & & G3 & .96000 & 1.36913 & .765 & -2.4346 & 4.3546 \\
\hline & G3 & G1 & -.41000 & 1.36913 & .952 & -3.8046 & 2.9846 \\
\hline & & G2 & -.96000 & 1.36913 & .765 & -4.3546 & 2.4346 \\
\hline \multirow[t]{6}{*}{ Week 1} & G1 & $\bar{G} 2$ & $22.4222^{*}$ & 7.2567 & .013 & 4.347 & 40.497 \\
\hline & & G3 & 11.3111 & 7.2567 & .282 & -6.764 & 29.386 \\
\hline & $\overline{\mathrm{G} 2}$ & G1 & $-22.4222^{*}$ & 7.2567 & .013 & -40.497 & -4.347 \\
\hline & & G3 & -11.1111 & 7.4452 & .312 & -29.656 & 7.434 \\
\hline & $\overline{\mathrm{G} 3}$ & $\overline{G 1}$ & -11.3111 & 7.2567 & .282 & -29.386 & 6.764 \\
\hline & & G2 & 11.1111 & 7.4452 & .312 & -7.434 & 29.656 \\
\hline \multirow[t]{6}{*}{ Week 2} & G1 & G2 & $61.5000^{*}$ & 15.7428 & .002 & 22.186 & 100.814 \\
\hline & & G3 & -1.0429 & 17.3477 & .998 & -44.365 & 42.279 \\
\hline & $\overline{\mathrm{G} 2}$ & $\overline{\mathrm{G} 1}$ & $-61.5000^{*}$ & 15.7428 & .002 & -100.814 & -22.186 \\
\hline & & G3 & $-62.5429^{*}$ & 17.3477 & .004 & -105.865 & -19.221 \\
\hline & $\overline{\mathrm{G} 3}$ & G1 & 1.0429 & 17.3477 & .998 & -42.279 & 44.365 \\
\hline & & $\mathrm{G} 2$ & $62.5429^{*}$ & 17.3477 & .004 & 19.221 & 105.865 \\
\hline \multirow[t]{6}{*}{ Week 3} & G1 & $\overline{G 2}$ & $152.0000^{*}$ & 34.5021 & .001 & 65.838 & 238.162 \\
\hline & & G3 & 16.8429 & 38.0194 & .898 & -78.103 & 111.788 \\
\hline & $\overline{\mathrm{G} 2}$ & $\overline{\mathrm{G} 1}$ & $-152.0000^{*}$ & 34.5021 & .001 & -238.162 & -65.838 \\
\hline & & G3 & $-135.1571^{*}$ & 38.0194 & .004 & -230.103 & -40.212 \\
\hline & $\overline{\mathrm{G} 3}$ & $\overline{\text { G1 }}$ & -16.8429 & 38.0194 & .898 & -111.788 & 78.103 \\
\hline & & G2 & $135.1571^{*}$ & 38.0194 & .004 & 40.212 & 230.103 \\
\hline \multirow[t]{6}{*}{ Week 4} & G1 & G2 & $156.7889^{*}$ & 42.1771 & .003 & 51.461 & 262.117 \\
\hline & & G3 & 2.5250 & 43.5424 & .998 & -106.213 & 111.263 \\
\hline & $\mathrm{G} 2$ & G1 & $-156.7889^{*}$ & 42.1771 & .003 & -262.117 & -51.461 \\
\hline & & G3 & $-154.2639^{*}$ & 44.6046 & .006 & -265.654 & -42.873 \\
\hline & G3 & G1 & -2.5250 & 43.5424 & .998 & -111.263 & 106.213 \\
\hline & & G2 & $154.2639^{*}$ & 44.6046 & .006 & 42.873 & 265.654 \\
\hline
\end{tabular}

*. The mean difference is significant at the 0.05 level.

\section{AUTHORS PROFILE}

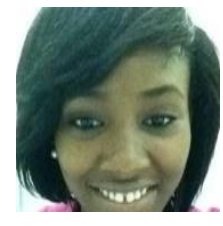

Ihuoma Q. Okpala is of the Department of Biological Sciences, Covenant University, Ota, Nigeria

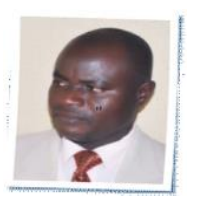

Solomon U. Oranusi (Ph.D) is of the Department of Biological Sciences, Covenant University, Ota, Nigeria.

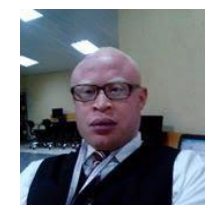

Hilary I. Okagbue (Ph.D) is of the Department of

Mathematics, Covenant University, Ota, Nigeria. 